\title{
An Overview of Taboo and Superstition among the Yoruba of Southwest of Nigeria
}

\author{
Odejobi Cecilia Omobola, Ph.D \\ Institute Of Education, Faculty Of Education \\ Obafemi Awolowo University, Ile-Ife, Osun State, Nigeria. \\ Email: bolaodejobi1@gmail.com
}

Doi:10.5901/mjss.2013.v4n2p221

\begin{abstract}
A taboo is something looked down upon by society because of social custom. This article therefore examines an overview of taboo and superstition among the Yoruba of southwest of Nigeria. This work explores the concept of taboos in Yoruba land. It also confirmed whether superstition and taboo means the same thing in Yoruba society. The importance of taboos in Yoruba society is also discussed. It was discovered that taboo in the concept of Yoruba belief is different from superstition because of its usefulness in the society.
\end{abstract}

Key Words: taboo, superstition, social custom, Yoruba society, Yoruba belief

\section{Introduction}

Taboos and superstitions were introduced to regulate the moral order of the society. They took their origin from the fact that people discerned that there were certain things which were morally approved or disapproved by the deity. These are not contained in any written law but are preserved in the tradition. Agboola and Mabawonku (1996) asserted that taboos and superstitions were often regarded as integral part of traditional education. Every society in the world cares for its tradition because in a society without schools, a type of education known as traditional/informal education goes on. In Yoruba societies, traditional education is supported and encouraged because of its contribution to the growth, renewal and development of the society (Oduyale, 1985; Idowu, 1962). According to Callaway (1964) the society absorbs or socializes its youth into its norms, religious beliefs and moral values as well as the collective opinions of the whole society through its traditional education. It is believed that traditional education is the prevailing practices that were responsible for the survival of a given society before the introduction of modern scientific inventions (Oladele, 1996).

Taboos and Superstitions were found in the early man's effort to explain nature and his own existence, to propitiate fate and invite fortune; to avoid evils he could not understand and to pry into the future. They are therefore deeply rooted in the culture as well as the religious beliefs of the society. A culture as a sociological construct is a complex phenomenon. It takes time and conscious effort to be able to understand a particular culture. As a complex reality, culture consists of many elements which are essential to the very nature of that culture and without them such a culture would not have taken the shape it has now. (http://mojaafryka.weebly.com/taboos.html 2012). Hence the notion of taboos and superstitions has been a vital component of African religion and culture especially among the Yoruba of Southwest of Nigeria. In fact, certain norms and code of conduct such as taboos were entrenched which facilitate orderly maintenance of the society. They are not written in any revealed law. People learn them, practise them and teach others in the society.

Therefore,the purpose of this work is to explore the concept of taboos in Yoruba land. It is also, to confirm whether superstition and taboo means the same thing in Yoruba society. The importance of taboos in Yoruba society is also discussed.

\section{Concept of taboo and superstition}

Etymologically, taboo is a derivation of the Polynesian term 'tapu' which means forbidden (Blakemore and Shelia 2001). It is similar to the sacer in the Greek, Kadesh in Hebrew and Nso in lgbo language of Nigeria and mmusu in Akan 
language (Osei 2006). Within its historical context taboo was a sacred term for a set of cultic or religious prohibitions instituted by traditional religious authorities as instruments for moral motivation, guidance, and objectivity for protecting the sanctity of their shrines and the well-being of their worshipping communities. The term is also applicable to any sort of social prohibition imposed by the leadership of a community regarding certain times, places, actions, events, and peoples in order to regulate contacts between a particular circumstance but not exclusively, for religious reasons for the well-being of the society. In another vein, taboo shade into other rules of law, custom, or morality; they indicate membership of a given community, just as they support the dominant social system.

Taboo may therefore be used in two senses. The narrower sense represents the cultic or purely religious usage, while the broader sense represents its usage in socio-economic and political contexts. Therefore cultic or religious taboos represent a subset of taboos, but not taboos as a whole set. For the same reason, religion is useful, but not a necessary condition for the existence and existential application of taboos (Osei 2006).

While certain taboos are only prevalent in specific cultures, there are some taboos that are thought of as universal, such as swearing, cannibalism, incest, and murder. Using profane language is considered disrespectful. It is not appropriate for people to walk around cursing other people, or even themselves. In addition, killing someone is obviously illegal anywhere in the world. There is no justification for murder, and it is a taboo worldwide. Incest is also a known universal taboo that is rarely talked about. Certainly, the various taboos in the world today help to define certain cultures and help to characterize the people who live in them. Without taboos, societies would be left unstructured and with few rules. Taboos serve as a set of social norms and help to explain the division between what is appropriate and inappropriate. While different cultures hold a variety of taboos, the general purpose for all of them is the same. Some might be considered silly and impractical to others, but that is what makes each culture unique. Taboos do not only constitute a part of African cultural heritage but also provide a good explanation of that heritage (http://mojaafryka.weebly.com/taboos.html. 2012).

According to Holden (2000), taboos are not a feature of 'primitive' societies' as it was assumed sometime ago by some anthropologists but it is a characteristic of any society. In fact, Durkheim calls taboos a "phenomenon that is universal" (Durkheim, 1963).Radcliffe-Brown (quoted in Steiner, 1956) talks about taboos in terms of ritual avoidance which closely connected with ritual prohibition. Ritual prohibition is a rule of behaviour which is associated with a belief that an infraction will result in an undesirable change of ritual status which is conceived in many different ways in different societies, but everywhere there is the idea that it involves the likelihood of some minor or major misfortune which will befall the person concerned. Taboos contain within them a certain quality of danger that will befall those who break it (Ahn, 2003). Steiner therefore concludes that "taboo is concerned (1) with all the social mechanisms of obedience which have ritual significance; (2) with specific and restrictive behaviour in dangerous situations. One might say that taboo deals with the sociology of danger itself, for it is also concerned (3) with the protection of individuals who are in danger, and (4) with the protection of the society from those endangered - and therefore dangerous - persons".

Webster (quoted in Magesa, 1997) describes taboos in similar terms that they represent "a system of prohibitions with regard to certain persons, things, acts or situation. The objects considered as taboo are perceived to contain within them certain assumed danger that always has repercussions against anyone who transgresses them though it may not be well defined or perceived immediately by senses. However, the consequences of that danger will always affect the one who broke a taboo.

On the other hand, Superstitions were found in the early man's effort to explain nature and his own existence, to propitiate fate and invite fortune; to avoid evils he could not understand and to pry into the future. A superstition is a belief or a practice that is not based on facts or events that can be proven (Kagan, 2012). For instance, some people believe in the superstition that if a black cat crosses your path, you will have bad luck. The reason this is called a superstition is because no one can prove that any bad luck encountered arose from having a black cat cross on one's path and what it would mean to have bad luck is also something that cannot be defined (Encyclopedia Britannica. 2009). Superstitions primarily represent the underlying inherent fear of mankind, caused by the uncertainties of this world. In a way, it is a sign of acceptance of our ignorance and limitations of our power. In another way, it is a sign of accepting the grandness of this universe and its scheme of operation, which is still largely beyond our comprehension and understanding (Kumar 2009). Therefore, the term superstition is usually referred to as belief or influence that is incapable of being justified on rational grounds. They are the irrational beliefs that an object, action or circumstance not logically related to a course of events influences its outcome.

It is designated to those beliefs that result from ignorance and fear of the unknown. Many superstitious practices are due to the false interpretations of the natural events (Valeed 2012). A superstition is a behavior that has no rational basis or history or a history that is long-lost. Many of them are age-old and inherited as part of our cultural heritage 
though not all superstitions are from our ancestors. They can easily be created and can be personal. For instance, a student writes a good form of literary piece with a certain pen, and from that moment the pen is lucky; a horse player may be convinced that black horses run well for him (Bjurstrom 2009). Hence, superstitions may be classified roughly as religious, cultural and personal.

\section{The importance of taboos}

The importance of taboos, according to Steiner (1956) is seen in maintaining harmony between God and spirits (invisible world) and human beings and the rest of creation (visible world). This harmony would be ruled "by moral order which is preserved by tradition and, if followed, have the power or force to sustain the existence and operation of the universe, ensuring a bountiful life for humanity (Magesa, 1997). To preserve that harmony is the duty of a human being, which determines his character and influences the quality of life of a community and the universe itself. Taboos are then seen as a moral ambience or moral codes intended to create harmony and the order of the existence of the universe (Magesa, 1997). Taboos clarify which attitudes and behaviours are not acceptable because they do not assure the continuation of life in its fullness, do not enhance the quality of life of the community and do not preserve the social code of behaving. Hence, breaking of a taboo endangers life and is seen as bad and wrong because it interrupts peace and harmony (Andemariam, 2001).

\section{The role of taboo in the Yoruba society}

In the traditional African society especially in Yoruba society, taboos played significant and positive roles.

- They provided a set of rules serving as a moral guidance or a law in the community to ensure that peace and security were present in the community. According to Osei (2006) every moral system requires the existence of guiding principles, source(s) of motivation, and some grounds for objectivity. Even though formulated as 'negative' principles stressing 'do not...' and teaching people about what was not acceptable in the society, by implication, they were also pointing out to the actions that were supposed to be done. By preventing people from doing wrong things, they were helping them to focus on what was encouraged in the society. In a society where there was no police, taboos served as a guardian of moral values. To a certain extent, they were better than modern law enforcing agencies, because, in most cases, breaking of a taboo was associated with an automatic punishment - one did not have to be caught to be punished;

$>$ They helped in the upbringing of children and provided rules for marriage: They could be described as 'teaching aids' when explaining some moral principles to them. When one lacked an intellectual ability to impart the importance of some moral principles, taboos were a useful way of transmitting the same value from a different perspective. Those values, worded as taboos, were expressed at various occasions such as circumcision, marriage negotiations and funeral rites. It was an effective system of preserving and transmitting moral values, keeping in mind that traditional African culture was an oral one.

$>$ They were a means of social control and without them there would be chaos: The motivation for abiding by the normative principles are provided and reinforced by the religious sanctions from the gods and the ancestors or directly from the Supreme Being.

$>$ Keeping of taboos ensured good harmony between the visible and the invisible world: Taboos represent the main source of the guiding principles regulating and directing the behavior of individuals and the community towards the Supreme Being and especially the gods and the ancestors in Yoruba society. Those found guilty of serious moral or legal violations are made to undergo ritual cleansing as a means of moral or ontological purification and transformation.

$>$ People seemed to be aware that behind prohibitions laid the true meaning of taboos - preserving harmony and well-being in and of the community: Life and its quality was seen as crucial and the society applied a variety of methods to preserve it and transmit it, especially through taboos. While well-being virtues include modernization, democratization qualitative education, and critical consciousness, the well-being vices include dependency, bribery and corruption, unwarranted military interventions, dictatorships and the abuse of human rights etc. Consequently, if one could show that a given set of taboos, xyz, promote some well-being virtues and help diminish some well-being vices one would have shown by implication that some taboos promote development and harmonious living (Osei, 1995). 
It is obvious from the forgoing that taboo is not a culture to be waved off so easily because it is a fruit of the society and functional within the context of the society. One could rightly say that in Yoruba worldview, taboo is different from superstition because it regulates moral order of the society. Hence, parents make use of them to inculcate good behavior in their children. Thorpe (1967) highlighted seven reasons why taboo came into being. They are to:
(a) avoid accident;
(c) respect elders;
(e) teach moral values;
(g) explain things that are difficult to understand.

(b) have respect for religion;

(d) obey rules of cleanliness;

(f) guide against being wasteful;

Therefore, if people kept taboos, some of the difficult situations such as post-election violence in Nigeria especially in Yoruba society, inter-tribal fighting, insecurity, drinking problems would not be experienced both in Yoruba land and Nigeria as a whole. It is worthy of note that the impact taboo exercised in the contemporary society seems to have diminished in comparison with a traditional African society. It is due to influence of Christianity that, to a certain extent, took over the role played by taboos and to the present style of life where people from many various tribes live together in contrast to the traditional set up whereby people of one tribe used to live in one area like we have in Yoruba society.

This weakening of the impact of taboos on daily life is also due to, mainly oral way of transmitting them from one generation to another. As a result people living in towns tend to know less about taboos because they are away from what would be considered their ancestral land and from the elders who played an important role in teaching about taboos.

\section{Types of taboos in Yoruba society}

A wide variety of taboos was collected from various Yoruba communities in southwest of Nigeria. Here are some examples of various taboos classified by the researcher using seven categories mentioned by Thorpe (1967):

\section{* Taboos to avoid accident}

- Aboyun ko gbodo dobale sun; ki omo re ma baa ku (a pregnant woman must not sleep with the stomach : so that the child will not die). This is to guard against having a stillbirth. If a pregnant woman sleeps with her stomach it will be difficult for the fetus to kick while still in the stomach and this may claim the life of the baby.

- $\quad$ Okunrin ko gbodo ba aboyun lo po bi oyun re ba ti too bi; ki okunrin naa ma baa tosi (a man must not have sexual intercourse with a pregnant woman whose expected day of delivery is near; to avoid becoming wretched). It not convenient for a pregnant woman nearing delivery to be having sexual relationship. If the man has any infection like gonorrhea, it may be contacted by the baby and the baby may become blind.

- A ko gbodo fi ada sa ile lasan ; ki omo onile ma baa binu si eni naa (we must not use the cutlass to till bear ground; so as not to incur the wrath of the earth goddess ). This taboo is to avoid been cut when cutlass is used to till bear ground instead of using it for clearing or planting.

- Omode ko gbodo fi igi fa ila sile; bi eera ba ko si oju ila naa, iya omo naa yoo ku (a child must not use stick to draw a line on the ground; if ants enter the line, the child's mother will die). When a child plays with a stick, it may accidentally enters into his/her eye and caused damages. If the mother of such child is an invalid, the worries may lead to her death hence the taboo.

- A ko gbodo gun igi ibepe; eni naa yoo ku (we must not climb pawpaw tree the person who does so will die). Pawpaw tree is not strong enough for anybody to climb. It may break and cause serious body injuries which may eventually lead to death

\section{* Taboo about Religion}

- A ko gbodo la Bibeli mole; ki ori fifo ma ba a pa eni naa (the Bible must not be dropped on the ground so that headache will not kill the person ). The Bible is a sacred book of Christians which must be handled with care to avoid being dropped to the ground. This taboo is to instill fear into a careless person to handle The Book with care.

- A ko gbodo ke bi egungun laiwo aso egungun; Oro ni yoo gbe eni naa lo (we must not sound like a masquerade to avoid being kidnapped by Oro ). Egungun is one of the traditional religions in Yoruba land. The taboo was put in place so that people will have respect for Egungun religion because whoever Oro kidnapped will never be seen again.

- Obinrin ko gbodo wo igbo Oro; ki Oro ma ba a gbe e (women must not enter the Oro grove to avoid being kidnapped by Oro). This taboo is also put in place to have respect for Yoruba traditional religion. Women are forbidden to know the secret of this hence only men propitiate it. 
- Olorisa-oko ko gbodo je isu egbodo; ki segede ma ba a mu un (the Olorisa-oko must not eat new yam so as not to have mumps). The causes of mumps are not clear to people. They now tie it to the eating of new yam by any of their members before the oracle. This is to instill fear into the Olorisa-oko religion not to eat new yam until their Orisa does so.

\section{* Taboo on Respect for Elders}

- Omode ko gbodo wo agba loju; lati fi han pe omo naa ni iberu ati owo fun agba (a child must not look at the elder by the eye; to show that the child have fear and respect for the elder). It is a culture in Yoruba land that children must not look up when elders are talking. It is a sign of disrespect for a child to look up and stare at the elders' face.

- Omode ko gbodo da si oro agbalagba; lati fi han pe omo naa ni eko iwa rere (a child must not talk when elders are talking; to show that the child have home etiquette). When elders are talking, it is improper for children to talk because such behaviour does not portray good home training and it is a sign of disrespect for elders.

- Omode ko gbodo na obi re; ki osi ma baa ta omo naa pa ( a child must not beat up his/her parents to avoid being wretched ). This is to show absolute respect for our parents.

\section{* Taboos on cleanliness}

- Aboyun ko gbodo jeun ninu isaasun obe; ki idi omo re ma ba a dudu (a pregnant woman must not eat in a soup cooking pot; so that her child's buttocks will not be black). It is a sign of laziness and dirty habit for any person especially a pregnant woman to eat in a soup cooking pot when there are serving plates in the house. It is bad because when the soup in the pot is leaked, her saliva will come into the pot meant to cook soup for the entire family.

- A ko gbodo we owo sinu awo ti a fi jeun, ki aya ma rin eni ti yoo tun fi awo naa jeun ( we should not wash our hand in the plate we used to eat so that those who will use the plate after may not feel nauseated). This taboo is to keep ethics of cleanliness. It is a dirty habit to wash hand in the plate after eating in it because of the filthiness already in the hand after the meal. Anyone who saw this dirty habit may feel nauseated to use the plate again.

- a ko gbodo subu ni baluwe, ki iru eni bee ma ba ku (one must not fall down in the bathroom, so that the person will not die). Everybody in the house take their bath and urinate in the bathroom. This frequent use may make the room to be slippery. If the bathroom is not washed properly and become slippery it may cause accident which may actually lead to death. So this taboo was put in place to keep the rules of cleanliness by washing the bathroom always.

\section{* Taboos on moral values}

- Obinrin ko gbodo ki owo bo apo aso oko re, ki omo re ma baa jale ( a woman should not deep her hand into the pocket of her husband, so that her children will not be stealing around). This is to effect good habit. If a woman deeps her hand into her husband pocket to take money her child who saw her may think it is proper to do so.

- A ko gbodo jeun ni idubule, ki ounje ma baa pa wa lori (we must not eat while lying down, so that the food will not go to a wrong place, e. g. our head). This is to learn the ethics of table manner. It is not proper and against table manner to eat while lying down. The food may go the wrong way thereby causing problem.

- A ko gbodo ro ala ni osan, ki ala naa ma baa se (dreams should not be relayed in the afternoon, so that the dream will not come to pass). Whoever relay dream in the afternoon is termed to be a jobless person. This taboo teaches us not to be lazy.

- A ko gbodo ta ayo ni owuro, ki oju eni naa ma baa fo (one must not play ayo game in the morning to avoid being blind). Morning time is meant for hard work and not play. If anybody takes joy in playing ayo game in the morning, the person is termed as a never to do well. Therefore, to instill fear of becoming blind on the person the taboo was put in place.

\section{* Taboo against being wasteful}

- A ko gbodo da iyo sinu ina, ki ara eni naa ma baa fin patapata (we must not throw salt into fire so that the person's body may not become speckled). During the time of our fore-fathers, it is very difficult to get salt. It was the colonial masters that brought salt to the shores of Nigeria in an exchange for slave. Therefore salt is not a commodity to be wasted.

- A ko gbodo fi odo sinu oorun, ki aara ma baa pa eni naa (mortar should not be left in the sun so that lightening will not strike the person dead): - mortar is a household utensil and very difficult to carve. It must be properly taken care of because if it is left in the sun, it may break. To avoid wasting the mortar, the taboo was put in place.

\section{Taboo on things that are difficult to explain}


- Afin ko gbodo je iyo, ki ete re ma baa bo (an albino must not put salt in his/her food so that his/her lip may not peel). People do not know the reason for the peeling of an albino's lip. They thought it was as a result of a particular food he/she ate and because salt is sharp, they concluded that it was salt that caused the peeling of albino's lip. Scientifically this has been proved wrong. Scientist have made it clear that eating of vegetables and fruits are very essential to our wellbeing and that eating of unbalanced diet can cause skin disease.

- A ko gbodo fi owo gbe ojo, ki aara ma baa san pa eni naa (we must not use bear hand to collect rain water during rain fall, so that thunder will not strike the person dead). This taboo was put in place to avert accident that thunder might cause if anybody collect rain water with hand during rainfall. It is very difficult for people to give accurate explanation for this scientifically.

\section{Conclusion}

The foregoing exposition and analysis of various types of taboos have demonstrated that most Yoruba traditional taboos enhance development in the society. It is also obvious from the forgoing that taboo in Yoruba concept is functional. It is not just a means of creating fear into the children. Taboos have played important roles in the traditional African Yoruba society and also exercise great influence on the modern society as well. They helped people to preserve moral rules that help them as individuals and as communities to live a peaceful and harmonious lives. Though formulated in forms of 'don'ts' and sometimes being ambiguous, they enabled people to maintain the moral order and hierarchy in the society. In the contemporary society, which in a number of aspects is quite different from the traditional one, there is a need to enforce taboos or to come up with an alternative way that will promote traditional values.

\section{References}

Agboola, T. \& Mabawonku, A.O. (1996). Indigenous knowledge environmental education and sanitation: application to an African city. In Warren, D. M., Egunjobi, L. and Wahab, B. (eds.) indigenous knowledge in education. Ibadan. Indigenous knowledge study group.

Ahn, J,B-K. (2003). "Sexual taboos and morality among the Agikuyu people of Kenya". In Katola, M (Ed). MIASMU Research Integration Papers to Moral Teaching and Practices of African Religion. Jan-Apr semester.

Andemariam, M. (2001). "Place of taboos in Gikuyu morality". In Magesa, L. (Ed). MIASMU Research Integration Papers to Moral Teaching and Practices of African Religion. August session

Bjurstrom, L. (2009). How do superstitions originate? http://www.helium.com/items/1615718-superstitions-and-origins

Blakemore, C. And Shelia J. (2001). Taboos. Oxford. Oxford University Press http://www.encyclopedia.com/topic/taboo.aspx\#2

Callaway, A. (1964). Nigeria indigenous education: the apprenticeship system. Odu . University of Ife journal of African studies 1 (1).

Cassier, E. (1972). An Essay on Man Introduction to a Philosophy of Human Culture. New Haven and London, Yale University Press.

Durkheim, E. (1963). Incest: The nature and the origin of the taboo. New York: Lyle Stuart.

Encyclopedia Britannica. (2009). Superstition. Encyclopædia Britannica Online. 13 Nov. 2009

Holden, L. (2000). Encyclopedia of Taboos. Oxford: ABC CLIO Ltd.

Oladele, F. K. (1996). The integration of Indigenous knowledge system (IKS) into courses in Polytechnic curriculum. In Warren, D. M., Egunjobi, L. and Wahab, B. (eds.) indigenous knowledge in education. Ibadan. Indigenous knowledge study group.

Oduyale, O. (1985). Traditional education in Nigeria in Oyeneye, O. Y and Shoremi, O. M (eds.) Nigerian life and culture. Ogun state University, 230-244.

Idowu, E. B. (1962). Olodumare: God in Yoruba belief. Longmanns. Ibadan.

Kagan M. (2012). What is superstition? Whyzz. Publications LLC

Lexicon Universal Encyclopedia (1989). Taboo. N.Y Lexicon pub. Inc.v.19 p. 57.

Lexicon Universal Encyclopedia (1989). Superstition . N.Y Lexicon pub. Inc.v.18 p. 353.

Magesa, L., (1997). African Religion: the Moral Traditions of Abundant Life, Maryknoll, New York, Orbis Books, passim.

Steiner, F. (1956). Taboo. London: Cohen \&West Ltd Taboos http://mojaafryka.weebly.com/taboos.html. retrieved: 15-08-2012

Thorpe, C. O. (1972). Àwon èèwò ilè Yorùbá. Onibon-Oje press. Ibadan.

Osei, J. (1995). Towards the Philosophy of Development: Africa's Dilemma of Development and the Way out, International Third World Studies Journal and Review, Vol 7

Osei, J. (2006 ). The Value of African Taboos for Biodiversity and Sustainable Development http://www.jsdafrica.com/Jsda/Fall2006/PDF/Arc_the\%20Value\%20of\%20Arican\%20Taboos.pdf

Kumar, V. (2009). Reasons why people believe in superstitions http://www.helium.com/items/1602118-reasons-for-superstitions-whysuperstitions-explaining-superstitions-why-superstitions

Valeed, (2012). What are Superstitious Beliefs? - Why do People Believe in Superstitions? HubPages Inc. http://valeed.hubpages.com/hub/What-are-Superstitions 